\title{
UPAYA PENINGKATAN INTERAKSI DAN AKTIVITAS BELAJAR DALAM PEMBELAJARAN KOSAKATA DENGAN STRATEGI ANALISIS FITUR SEMANTIK
}

\author{
Ari Kusmiatun \\ FBS Universitas Negeri Yogyakarta
}

\begin{abstract}
This study is aimed at improving the process of learning Indonesian, especially the vocabulary, by means of the feature analysis strategy as an appropriate strategy to make students active and interactive in the learning process so that their vocabulary mastery and, in turn, their communicative competence can improve.

The subjects of the study were the second year students of Marketing Study Program, Vocational High School Abdi Negara Muntilan, Magelang. The steps in the study included problem identification, research design making, action, observation, and reflection. All were carried out in three cycles, each of which consisted of three actions. The research data were both quantitative and qualitative. All participants were involved in the data analysis to meet the criteria of data suitability comprising the democratic, process, and dialogic validity.

The research findings show that the feature analysis strategy in the vocabulary learning can improve (1) students' activity, 2) their interaction, and 3) their vocabulary mastery. The various activities and the optimum interaction among students prove that their communicative competence is better.
\end{abstract}

Key words: feature analysis strategy, vocabulary, activities, interaction

\section{A. Pendahuluan}

1. Latar Belakang

Asumsi tentang hakikat pembelajaran bahasa yang lebih menekankan pada penggunaan bahasa sebagai alat komunikasi menjadikan arah pembelajaran bahasa di sekolah cenderung pada peningkatkan kemahiran komunikatif siswa. Pemberian materi yang berupa keterampilan lebih diutamakan daripada yang berupa pengetahuan. Tujuannya adalah untuk mengembangkan kompetensi komunikatif siswa agar siswa mampu berkomunikasi secara baik sesuai situasi dan konteks yang dihadapinya.

Kemampuan seseorang dalam berbahasa salah satunya bergantung pada kemampuannya menguasai kosakata.
Tanpa penguasaan kosakata yang memadai, tidak mungkin seseorang dapat berkomunikasi, baik lisan maupun tertulis dalam bahasa tertentu. Kosakata menjadi sangat berarti karena semua kegiatan kebahasaan akan selalu menggunakan kosakata di dalamnya. Di dalam materi bahasa Indonesia untuk jenjang sekolah menengah kejuruan (SMK), kosakata merupakan unsur materi terbanyak yang terintegrasi ke dalam semua ranah pembelajaran bahasa yang meliputi pengetahuan kebahasaan, kesastraan, dan keterampilan berbahasa. Dengan menguasai banyak kosakata, seseorang akan mampu berkomunikasi dengan baik.

Kenyataan di lapangan, menunjukkan bahwa pembelajaran kosakata 
merupakan hal yang menarik sekaligus membosankan bagi siswa. Kegiatan belajar kosakata menjadi menjenuhkan karena siswa diposisikan hanya sebagai pendengar dan pencatat saja, tidak ada kegiatan yang menuntut aktivitas siswa secara interaktif. Guru berperan sebagai 'kamus berjalan' yang menjawab pertanyaan siswa tentang kosakata yang belum diketahui oleh siswa. Para guru mengeluh kesulitan untuk menggerakkan siswa agar belajar kosakata secara aktif dan mandiri. Mereka mengakui bahwa terdapat kesulitan mengajarkan kosakata, padahal kosakata mempunyai porsi yang cukup banyak dalam materi yang hams diajarkan.

Berdasarkan prasurvey yang dilakukan oleh peneliti bersama kolaborator dengan mengamati kelas dan mewawancarai beberapa mahasiswa pada tanggal 26, 29, dan 31 Juli 2003, tampak bahwa siswa yang menjadi subjek penelitian memang cenderung tidak menunjukkan respons yang positif terhadap pembelajaran kosakata. Strategi yang selama ini digunakan guru, yakni siswa menanyakan kata sukar dan guru langsung memberikan jawabannya, ternyata memperlihatkan adanya hal negatif dalam pembelajaran kosakata. Siswa tampak enggan untuk belajar dan mereka tidak responsif terhadap guru maupun teman yang lain. Siswa berperilaku pasif dan tidak interaktif, baik secara verbal maupun nonverbal. Interaksi yang terbanyak dari guru ke siswa, sedangkan interaksi dari siswa ke guru sangat terbatas, bahkan interaksi antarsiswa tidak ada. Sudah barang tentu kemampuan kosakata siswa juga kurang. Rendahnya pemahaman dan penguasaan kosakata pada siswa akan mempengaruhi kemampuannya dalam kegia tan berbahasa yang lainnya.

Pembelajaran bahasa Indonesia, khususnya kosakata, di sekolah ini be- lum menemukan cara yang tepat untuk memberi pengetahuan dan bekal yang sesuai dengan kebutuhan siswanya. Lulusan SMK diarahkan untuk dapat langsung terjun kedunia kerja. Oleh karena itu, siswa dituntut mampu aktif dan interakstif berbahasa, termasuk menguasai kosakata secara baik. Dengan demikian, kondisi di atas perlu perbaikan. Salah satu upaya adalah dengan mengguanakan strategi analisis fitur semantik dengan alasan bahwa strategi ini memungkinkan banyak aktivitas dan interaksi siswa dalam belajar kosakata serta membantu penguasaan kosakata pada siswa. Dengan partisipasi aktif siswa dan interaksi yang optimal dalam pembelajaran maka tujuan pembelajaran ke arah kompetensi komunikatif akan lebih mudah dicapai.

Banyak faktor yang mempengaruhi pembelajaran untuk meningkatkan kemampuan siswa dan menciptakan proses belajar yang edukatif. Terlebih lagi dalam Pembelajaran kosakata, faktor penentu keberhasilan dan kegagalan pembelajaran sangat kompleks. Terkait dengan latar belakang di atas, ada beberapa masalah yang teridentifikasi dalam penelitian ini antara lain kurangnya perhatian siswa dalam pembelajaran kosakata, rendahnya motivasi belajar, kurangnya keaktifan siswa dalam pembelajaran, dan dominasi peran guru. Selain itu, masalah lainnya adalah terpolanya kebiasaan untuk mendengar dan mencatat pada siswa, terbatasnya fasilitas belajar, materi yang hanya berdasarkan buku paket sehingga kurang dapat memenuhi kebutuhan siswa, kurangnya variasi mengajar guru sangat, dan kurangnya keberanian siswa untuk berinteraksi (khususnya secara verbal).

Dari sekian banyak masalah yang ada, peneliti memfokuskan penelitian pada masalah aktivitas dan interaksi siswa, selain kemampuan siswa. Hal 
yang sangat berkaitan dengan itu adalah cara mengajar guru. Oleh karena itu, penelitian ini akan membatasi pada pemilihan strategi pembelajaran kosakata yang dapat merangsang keaktifan dan interaksi siswa yang sekaligus dapat meningkatkan penguasaan kosakatanya. Strategi yang akan diterapkan adalah strategi analisis fitur semantik. Pemilihan strategi ini didasarkan pada asumsi bahwa dalam strategi ini banyak memberikan kesempatan pada siswa untuk aktif dan interaktif dalam belajar kosakata.

Masalah yang ingin dicari pemecahannya melalui penelitian ini adalah apakah pemakaian strategi analisis fitur semantik dapat meningkatkan proses belajar kosakata sehingga siswa dapat aktif dan interaktif dalam pembelajaran sekaligus meningkat penguasaan kosakatanya?

\section{Tujuan}

Penelitian tidakan kelas ini dilakukan dengan tujuan memperbaiki proses pembelajaran bahasa dan sastra Indonesia, khususnya belajar kosakata, yang dapat menarik siswa untuk aktif dan interaktif dalam pembelajaran di kelas sehingga secara tidak langsung akan meningkatkan kompetensi komunikatif siswa. Selain itu, penelitian ini berupaya meningkatkan kemampuan siswa dalam penguasaan kosakata sekaligus sebagai upaya memperbaiki kinerja guru, khususnya guru bahasa Indonesia yang berfungsi sebagai ujung tombak pembelajaran.

\section{Landasan Teori}

\section{a. Pembelajaran Bahasa dan Kosaka-} ta

Permasalahan dalam pembelajaran bahasa sangat kompleks. Salah satu yang menentukan keberhasilan pembelajaran bahasa adalah pendekatan, me- tode, dan strategi yang digunakan dalam pembelajaran. Ketiga hal tersebut memiliki keterkaitan erat satu dengan lainnya dan sudah dikenal oleh guru dalam melaksanakan tugasnya seharihari. Akan tetapi, pengertian ketiganya sering dikacaukan.

Anthony (Syafi'ie, 1994: 17) menjelaskan bahwa pendekatan mengacu pada teori-teori tentang hakikat bahasa dan pembelajaran bahasa yang berfungsi sebagai sumber landasan atau prinsip pembelajaran bahasa. Metode diartikan sebagai perencanaan secara menyeluruh untuk menyajikan materi pelajaran secara teratur. Strategi lebih mengarah pada cara pembelajaran dilakukan, lebih kongkret, dan merupakan penjabaran dari metode. Strategi mengacu pada implementasi perencanaan pembelajaran di depan kelas.

Pembelajaran kosakata merupakan bagian dari pembelajaran bahasa. Penguasaan kosakata seseorang didukung oleh pembelajaran kosakata yang diperolehnya. Kosakata juga mempunyai peranan yang penting dalam kehidupan, khususnya di dalam komunikasi. Dengan penguasaan kosakata yang memadai, seseorang akan mampu berbahasa dengan baik dan lancar, baik produksi maupun resepsi. Nurgiyantoro (2001: 166) mengemukakan bahwa penguasaan kosakata dalam jumlah memadai diperlukan dalam kegiatan komunikasi dengan bahasa. Bahkan menurut Funk dan Lewis (Ramli, 2002: 219) kosakata dapat dipakai sebagai ukuran kepandaian seseorang. Makin banyak kosakata yang dimiliki seseorang, makin mudah dan kompleks pula ia dalam menyampaikan dan menerima informasi.

Nation (2002: 19) mengatakan bahwa "vocabulary learning is a cumulative process for any particular word". Hal ini berarti bahwa dalam pembelajaran kosakata terdapat sekumpulan proses un- 
tuk kata tertentu. Pertama kali bertemu dengan suatu kata, hal yang dilakukan pertama adalah mengenal kata tersebut. Pertemuan berikutnya sudah mengarah pada pencarian maknanya, dan seterusnya sampai benar-benar ia paham maksud kata tersebut.

Sejalan dengan hal tersebut, Blachowich dan Fisher (1996: 11) menyatakan bahwa: Vocabulary learning is long lasting when students use words in meaningful ways. Artinya, bahwa pembelajaran kosakata akan bertahan dalam pikiran apabila anak menggunakan kata-kata dalam makna penuh.

Berdasarkan beberapa pendapat di atas mengenai pembelajaran kosakata dapat diambil suatu simpulan bahwa pembelajaran kosakata merupakan suatu langkah mengenalkan dan memahamkan katakata pada siswa yang melibatkan kemampuan kognitif atau berpikir, bernalar dan emosinya. Hal ini senada dengan makna kata yang diartikan sebagai sekelompok ciri yang dimiliki oleh referensnya. Siswa dilibatkan secara intelektual dan emosional dalam pembelajaran kosakata.

\section{b. Jenis Strategi Pembelajaran Ko- sakata}

Di dalam pembelajaran kosakata terdapat bermacam-macam strategi untuk mengajarkan kosakata pada siswa. Nation (1994: 175-216) mengemukakan beberapa strategi mengembangkan kosakata berdasarkan pendapat para ahli, yang meliputi menebak kata dalam konteks, membangun kata, membuka kamus, dan mengontrol siswa.

Tierney (1990: 196-197) secara singkat mengupas beberapa strategi dalam upaya menemukan makna kata atau menguasai kosakata, antara lain possible sentences (tebak makna dalam kalimat), list-group-label, contextual redefinition (mendefinisikan kembali secara kontek- stual), preview in context (melihat dalam konteks), feature analysis (analisis fitur), dan key word method (metode kata kunci).

Banyak strategi untuk mengajarkan kosakata. Semuanya didesain untuk tujuan yang bermacam-macam, tetapi pada prinsipnya adalah untuk meningkatkan kemampuan seseorang dalam penguasaan kata. Tiap-tiap strategi memiliki kelebihan dan kekurangan. Guru sebagai pengajar harus dapat memilih dan mengkreasikan strategi yang akan digunakan dalam pembelajaran kosakata agar hasil yang maksimal dapat tercapai.

\section{c. Strategi Analisis Fitur Semantik (Semantic Feature Analysis)}

Strategi Semantic Feature Analysis banyak dikemukakan oleh para ahli. Patrick (1996) mengatakan bahwa "one of the ways to teach new vocabulary is semantic feature analysis."

Analisis fitur semantik adalah suatu strategi pengkategorian yang diperoleh dari konstruk teoretis dari struktur kognitif sebagai cara mengorganisasikan pengetahuan seseorang. Hal tersebut diungkapkan Tierney (1990: 210) yakni: "Feature analysis is a categorization strategy derived from the theoritical construct of the cognitive structure as the way in which individuals organize knowledge". Selanjutnya, dikatakan olehnya bahwa esensi strategi ini adalah penggunaan katagori sebagai sistem makna untuk menguatkan makna kata. Hal itu juga dikemukakan oleh Johnson \& Pearson (1984) yaitu, "Semantic feature analysis is an activity in which students identify important characteristics of a category of concepts."

Adapun langkah-langkah dalam strategi analisis fitur semantik, seperti diungkapkan oleh Tierney (1990: 210216), adalah sebagai berikut. 
a. Pemilihan kategori atau topik (category or topic selection),

b. Pembuatan daftar kata berdasarkan kategori (list words in category),

c. Pembuatan daftar karakteristik/ciri (list features),

d. Penentuan letak karakteristik kata (indicate feature possesion),

e. Penambahan kata-kata atau karakteristik (add words/features),

f. Melengkapi dan menjelaskan matriks (complete $\mathcal{E}$ explore matrix).

Melalui langkah-langkah dalam strategi ini, siswa diharapkan tidak sekadar menghafal makna kata, tetapi mencoba menganalisis kata untuk memperoleh maknanya bahkan lebih dalam untuk dapat mengamati persamaan dan perbedaan pada masing-masing konsep kata.

\section{d. Interaksi dan Aktivitas Siswa da- lam Pembelajaran Kosakata}

Interaksi adalah sebuah kata yang sangat penting bagi seorang guru bahasa. Hal tersebut diungkapkan oleh Brown (2001: 165) bahwa: "interaction is an important word for language teachers". Selanjutnya is menyatakan bahwa: "interaction is the collaborative exchange of thoughts, feelings, or ideas between two or mare people, resulting in a reciprocal effect on each other." (Brown, 2001: 165). Artinya, bahwa interaksi merupakan pertukaran pemikiran, perasaan, atau gagasan antara dua orang atau lebih yang menghasilkan pengaruh bagi mereka.

Interaksi ada berbagai macam berdasarkan arah komunikasi yang terjadi di dalam interaksi. Roestiyah (1994: 4148) mengemukakan beberapa macam bentuk interaksi belajar mengajar, antara lain interaksi searah, dua arah, dan optimal. Selain macam interaksi tersebut, interaksi belajar dalam kelas juga dapat dibedakan dari cara berinteraksinya, yaitu interaksi verbal dan nonverbal.
Interaksi dalam belajar kosakata mengutamakan aplikasi kata yang dipelajari ke dalam proses interaksinya, sedangkan dalam pembelajaran lain interaksi sebatas pada ada tidaknya hubungan komunikasi yang terjalin. Interaksi yang terjadi dalam pelajaran kosakata dapat diindikasikan dalam tingkah laku siswa, baik verbal maupun nonverbal.

Aktivitas dalam pembelajaran kosakata ini sejalan dengan prinsip bahwa belajar itu adalah berbuat (learning by doing). Diedrich (Sardiman, 1994: 100) membuat daftar yang berisikan 177 macam kegiatan siswa yang antara lain berupa visual activities, oral activities, listening activities, writing activities, drawing activities, motor activities, mental activities, dan emotional activities. Aktivitas siswa dalam pembelajaran kosakata ini diartikan sebagai suatu kegiatan yang dilakukan siswa selama proses pembelajaran berlangsung. Secara luas aktivitas menyangkut perilaku siswa, baik yang bersifat fisik maupun psikis. Kaitan kedua aktivitas itu akan membuahkan aktivitas belajar yang optimal.

\section{B. Metode Penelitian \\ 1. Subjek dan Objek Penelitian}

Subjek penelitian tindakan kelas ini adalah siswa kelas II Jurusan Penjualan 2 di Sekolah Menengah Kejuruan Abdi Negara di Muntilan. Objek penelitian adalah upaya peningkatan peran aktif atau interaksi siswa di kelas dan penguasaan kosakata siswa dalam pembelajaran kosakata dengan menggunakan strategi analisis fitur semantik.

\section{Desain dan Prosedur Penelitian}

Penelitian ini menggunakan desain penelitian tindakan kelas dengan model Elliott. Beberapa langkah yang terdapat dalam penelitian tindakan ini meliputi: ide awal, temuan dan analisis, perencanaan, implementasi langkah tindakan, monitoring, refleksi, revisi dan peren- 
canaan kembali tindakan selanjutnya. Penelitian ini dilakukan dalam tiga siklus. Strategi analisis fitur semantik ditindakkan sejak siklus pertama. Siklus yang berikutnya merupakan perbaikan dari siklus yang sebelumnya dengan beberapa perubahan dan modifikasi berdasarkan refleksi yang dilakukan secara kolaboratif.

\section{Teknik Pengumpulan dan Analisis Data}

Penelitian ini mengandung data kualitatif dan data kuantitatif. Data kualitatif berupa data perilaku siswa yang menunjukkan berbagai aktivitas dan adanya interaksi dalam pembelajaran. Data kuantitatif berupa tingkat penguasaan siswa yang ditunjukkan dengan nilai tes kosakata. Data atau informasi yang diperlukan dalam penelitian ini diperoleh melalui beberapa cara, yaitu: observasi kelas, wawancara, tes kosakata, penilaian proses belajar, dan angket.

Data akan dianalisis secara kuantitatif dan kualitatif. Analisist kualitatif dilakukan untuk data kualitatif yang berupa hasil observasi lapangan. Teknik analisis kuantitatif digunakan untuk menganalisis data kuantitatif, yakni yang berupa hasil tes kosakata, baik sebelum maupun sesudah tindakan diberikan.

\section{Validitas dan Reliabilitas Data}

Validitas yang digunakan di dalam penelitian tindakan ini adalah validitas demokratik (democratic validity), proses (process validity), dan dialogik (dialogic validity) yang merupakan sebagian validitas yang dikemukakan Burns (1999: 161-162). Untuk instrumen yang berupa tes kosakata, validitasnya meliputi validitas isi dan konstruk. Reliabilitas instrumen lain dilakukan dengan kesungguhan, kolaborasi, dan diskusi dengan orang lain yang lebih ahli di bidang yang bersangkutan selain trianggulasi.

\section{Hasil Penelitian dan Pembahasan \\ 1. Hasil Penelitian}

Penelitian ini menunjukkan adanya gelombang naik-turun interaksi siswa. Untuk interaksi searah di awal penelitian tampak sangat tinggi, siklus pertama belum ada perubahan yang berarti. Di siklus kedua terjadi penurunan yang cukup tajam lalu sedikit naik di awal siklus ketiga namun turun di akhir siklus. Hal ini senada dengan interaksi klasikal yang terjadi. Ada penurunan di siklus pertama, stabil siklus kedua dan naik sedikit di siklus ketiga. Interaksi dua arah justru sebaliknya. Di awal penelitian sangat rendah dan mulai menanjak di siklus pertama dan siklus kedua. Akhir siklus kedua terjadi penurunan, tetapi naik dan stabil di siklus ketiga. Hal ini hampir sama dengan yang terjadi pada interaksi individu yang mulai muncul di pertengahan siklus pertama. Interaksi optimal baru tercapai pada tengah siklus kedua dan meningkat sampai tengah siklus ketiga. Berikut grafik yang menunjukkan adanya gelombang interaksi tersebut.

Aktivitas Siswa juga naik-turun dalam penelitian ini. Aktivitas fisik siswa yang terdiri atas aktivitas oral, visual, audio, motorik, dan menggambar mengalami perubahan yang cukup unik dari siklus ke siklus.

Aktivitas visual, audio, dan mengambar meningkat tajam di awal penelitian tapi menurun di siklus satu, baru mulai naik siklus kedua dan stabil di siklus ketiga. Aktivitas oral tampak menurun dari awal siklus dan sangat tajam di siklus ketiga. Aktivitas motorik baru muncul dipertengahan siklus pertama dan semakin meningkat sampai akhir siklus penelitian. Berikut grafik tampilan visualnya. 
Grafik 1. Gelombang Interaksi Siswa

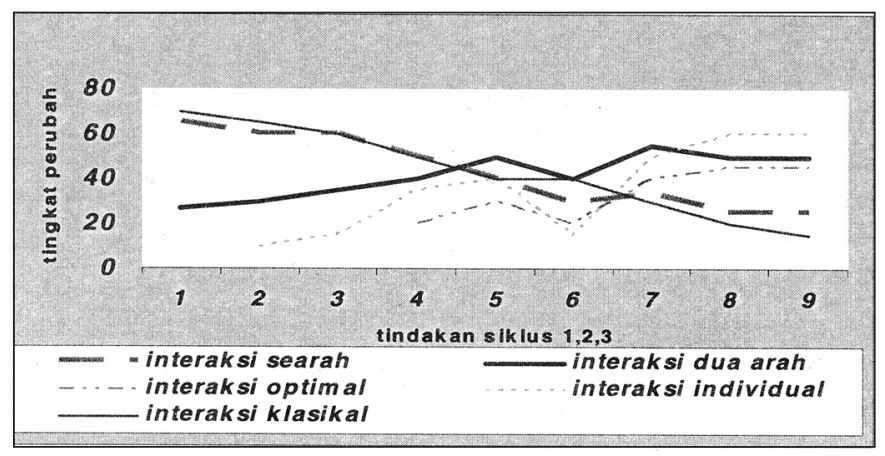

Grafik 2. Gelombang Aktivitas Fisik Siswa

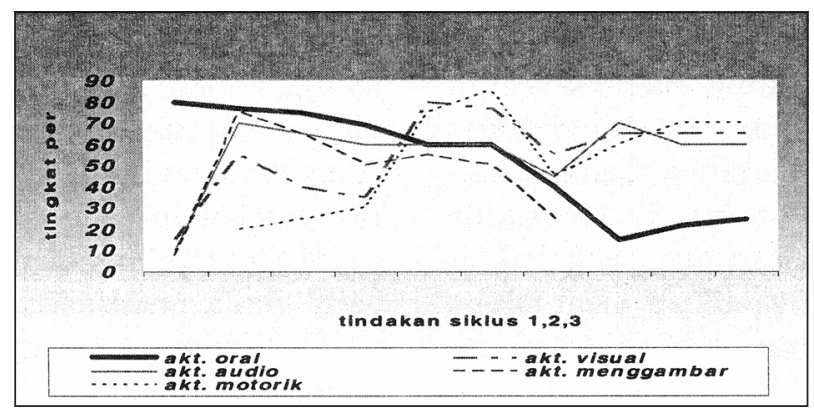

Grafik 3. Gelombang Aktivitas Psikis Siswa

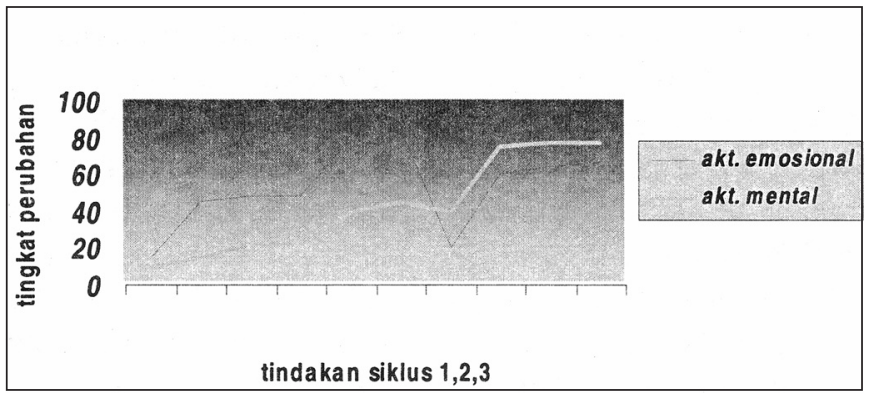

Aktivitas psikis siswa dilihat dari dua aspek, mental dan emosional. Aktivitas mental tampak semakin meningkat dari siklus pertama sampai siklus terakhir. Aktivitas emosional juga meningkat, hanya turun dengan tajam pada akhir siklus kedua dan mulai menanjak lagi di siklus ketiga. Grafik berikut menunjukkan hal tersebut.

\section{Pembahasan}

\section{a. Interaksi Belajar}

Interaksi siswa, baik verbal maupun nonverbal, berhasil dimunculkan selama penelitian tindakan ini. Interaksi nonverbal ada kemajuan yang cukup baik. Interaksi verbal sangat alot untuk ditingkatkan. 
Interaksi yang masih kurang berhasil untuk dimunculkan secara optimal adalah interaksi antarsiswa. Pada awal penelitian ini, kondisi kelas menunjukkan adanya siswa yang tidak interaktif, baik terhadap guru maupun pada siswa yang lain. Siswa mulai berinteraksi pada guru secara mandiri pada pertengahan siklus. Awalnya siswa berinteraksi dengan stimuli guru. Tanpa hal tersebut siswa kurang interaktif. Guru berpran dalam menggerakkan interaksi agar siswa termotivasi berkreasi. Sebagaimana yang diungkapkan Purwo (1997: 29) bahwa di dalam diri siswa terdapat dayua kreativitas yang dapat dikembangkan lewat berinteraksi.

Siswa pada awalnya masih berinteraksi secara klasikal. Seiring jalannya penelitian ini, interaksi klasikal mulai berkurang, sedangkan interaksi individual mulai muncul. Interaksi mulai kompleks pada siklus akhir walaupun belum sesempurna seperti yang diharapkan. Akan tetapi sudah mengarah pada salah satu prinsip interaksi, yakni communicative competence yang melibatkan seluruh kemampuan berbahasa siswa (Brown, 2001: 166).

Beberapa hal yang berpengaruh terhadap peningkatan interaksi adalah peranan guru dan siswa dalam pembelajaran, alat pendukung, materi atau bahan ajar, waktu pembelajaran berlangsung, dan strategi pembelajaran yang digunakan. Peranan guru dalam pembelajaran yang mendukung terjadinya interaksi adalah penciptaan kesempatan pada siswa untuk berinteraksi, sikap guru yang perhatian secara merata dan memotivasi siswa untuk interaktif, dan pemberian stimuli dalam mengajar yang memberi peluang siswa untuk interaksi. Dari siswa sendiri, interaksi akan muncul apabila ada dorongan, baik berupa tunjukan atau suruhan guru maupun hal lain. Hal lain itu misalnya reaksi dari tindakan guru yang mereka tidak inginkan atau juga merespons teman yang melakukan kesalahan. Selain itu, siswa sangat antusias untuk mendapat nilai sehingga tingkat interaksi meningkat.

Menurut para siswa, pada pembelajaran sebelumnya (sebelum menggunakan strategi analisis fitur semantik) sebagian besar dari mereka (48,65 \% siswa) merasa tidak ikut dilibatkan dalam pembelajaran. Akan tetapi, setelah pemakaian strategi ini temyata para siswa merasa terlibat dan senang jika teman yang lain juga aktif terlibat dalam interaksi belajar.

Sesuatu yang penting dalam membuat siswa berinteraksi adalah strategi guru mengajar. Penggunaan strategi analisis fitur semantik ternyata berhasil untuk memunculkan interaksi siswa. Interaksi yang terjalin tidak sekadar searah dan dua arah, bahkan interaksi antarsiswa juga dapat muncul. Akan tetapi, keberhasilan ini didukung kreativitas pengajar dalam menerapkan strategi tersebut sesuai kebutuhan, situasi dan kondisi yang dihadapinya. Juga membuat model-model lain yang menarik sebagai modifikasi bentuk analisis fitur semantik. Gelombang perubahan interaksi siswa dalam pembelajaran tersebut terlihat dalam grafik 1 .

\section{b. Aktivitas Belajar}

Aktivitas siswa menjadi objek pengamatan yang paling menarik selama penelitian. Pada dasarnya aktivitas fisik siswa dapat ditingkatkan dengan baik. Beberapa aktivitas fisik yang diamati, meliputi aktivitas oral, visual, audio, menggambar dan motorik. Dalam pembelajaran yang dilaksanakan terdapat kegiatan yang meliputi empat keterampilan berbahasa, yakni membaca, menulis, menyimak dan berbicara. Peningkatan yang cukup baik adalah pada aktivitas oral dan motorik, meskipun di 
siklus akhir terdapat penurunan aktivitas oralnya.

Dengan strategi yang baru ini siswa menjadi lebih aktif. Mereka lebih memperhatikan dalam pembelajaran dan melakukan banyak kegiatan. Awalnya guru masih memegang kendali dalam membuat siswa mau tergerak aktif. Akan tetapi, sejalan penerapan strategi mengajar kosakata yang baru siswa yang kemudian aktif tanpa suruhan guru.

Aktivitas oral yang banyak muncul berupa pertanyaan, pernyataan dan jawaban pertanyaan guru. Terkadang muncul juga sumbangan saran atau lebih tepatnya permohonan. Penerapan kosakata baru dalam aktivitas juga mulai berkembang dan berani dimunculkan siswa. Aktivitas visual yang dilakukan siswa berupa membaca, memperhatikan contoh dan gambar (media), memperhatikan pekerjaan orang lain, dan guru yang menerangkan. Aktivitas audio hanya sebatas mendengarkan penjelasan guru dan menyimak bacaan teman.

Aktivitas yang belum begitu diperhatikan guru adalah aktivitas menulis dan menggambar. Aktivitas motoriknya adalah saat siswa maju ke depan untuk melengkapi matriks dan mengisi TTS. Hal ini yang paling ramai dan paling disukai siswa. Tingkat perubahan aktivitas fisik siswa dalam tiga siklus yang dilaksanakan dapat dilihat dalam grafik 2 di atas.

Peningkatan aktivitas psikis melalui strategi analisis fitur semantik dapat berhasil dengan baik. Secara emosional, siswa sangat tertarik dan antusias menggunakan strategi yang baru. Mereka tampak bersemangat dan melakukan aktivitas belajar dan merasa bahwa pembelajaran kosakata menjadi menyenangkan. Kejenuhan dan kelesuan muncul di akhir tiap siklus dan kondisi belajar di waktu siang. Namun demikian, adanya perubahan tampilan strategi mengajar dan dibuatnya media pembelajaran dapat membuat siswa bergairah kembali. Keberanian siswa untuk melakukan kegiatan di kelas juga makin baik.

Aktivitas mental mengalami kemajuan yang bagus. Siswa menjadi dapat menanggapi yang dikemukakan gurunya. Pertanyaan yang secara rutin diajukan guru sebagai evaluasi dapat mengasah ingatan dan pemahaman siswa. Strategi yang baru ini menuntut siswa untuk dapat mengingat, memecahkan, menganalisis, memutuskan, menghubungkan kata dengan hal lain ke arah makna yang dicari. Siswa makin terampil melakukan semuanya itu. Grafik 3 menunjukkan adanya perubahan tingkat aktivitas psikis siswa tersebut.

\section{c. Penguasaan Kosakata Siswa}

Tingkat kemampuan siswa dapat ditingkatkan melalui strategi analisis fitur semantik. Berdasarkan hasil tes awal dan tes akhir yang dilakukan ada kenaikan hasil perolehan nilai siswa. Tes awal menunjukkan hasil 57,08, sedangkan tes akhir 67,24. Pada tes awal banyak atau sebagian besar jawaban siswa tidak terisi, sedangkan pada tes akhir jawaban yang tidak terisi hanya beberapa nomor saja pada sebagian kecil siswa.

Penerapan kebiasaan pretest pada setiap pertemuan sangat membantu siswa dalam menyiapkan diri dalam belajar. Penelitian ini menunjukkan hasil bahwa cara tersebut dapat membentuk suatu kebiasaan yang positif. Berdasar catatan guru dan pengamatan, makin lama siswa makin yakin untuk menjawab pertanyaan guru. Para siswa menjadi terbiasa dan siap mendapat pertanyaan. Kondisi tersebut menjadikan para siswa menjadi rajin belajar dan tidak lagi meremehkan pelajaran.

Kualitas jawaban mereka pun makin hari makin meningkat. Di awal sikius, 
jawaban yang diberikan cenderung hafalan dan masih membuka buku catatan, tetapi yang selanjutnya lebih pada daya penalaran siswa dan tidak tergantung buku catatannya. Siswa makin berani untuk menjawab dan mengeluarkan ide dalam pikirannya menggunakan kata yang diperolehnya. Tujuan pembelajaran kosakata dikatakan berhasil, yaitu mengajarkan penguasaan kata beserta maknanya (Purwo, 1997: 10). Peningkatan kemampuan siswa di dalam proses pembelajaran dapat diketahui dari kuantitas siswa yang semakin banyak aktif dan kualitas jawaban yang semakin baik.

Pada awalnya para siswa hanya sebatas pemahaman terhadap kata, penerapannya sangat kurang. Sejalan tindakan dilakukan mereka mulai dapat menggunakan kata dalam kalimat bermakna. Bahkan di akhir siklus mereka sampai dalam tataran wacana dalam memahami kata. Hal tersebut menunjukkan adanya peningkatan dalam hal kemampuan kosakata siswa.

\section{Simpulan}

Berdasarkan langkah-langkah penelitian tindakan yang telah dilakukan dan pembahasannya, maka dapatlah dikemukakan simpulan penelitian tindakan ini bahwa strategi analisis fitur semantik dapat digunakan sebagai upaya peningkatan dan perbaikan proses belajar kosakata di kelas 2 Pn2. Strategi analisis fitur semantik yang diterapkan terbukti dapat meningkatkan: (1) aktivitas belajar siswa, (2) interaksi dalam pembelajaran, dan (3) penguasaan kosakata siswa. Aktivitas belajar kosakata siswa menjadi bervariasi. Interaksi siswa menjadi lebih optimal. Peningkatan aktivitas dan interaksi tersebut menunjukkan adanya peningkatan kemampuan siswa selama proses pembelajaran. Peningkatan kemampuan siswa juga dapat dilihat dari meningkatnya rerata hasil dari pretes ke posttes dari 57,08 menjadi 67,24. Dengan demikian, proses pembelajaran kosakata di kelas 2 Pn2 mengalami kemajuan dan perbaikan. Proses belajar mengajar bahasa dan sastra Indonesia, khususnya kosakata, menjadi lebih berbobot, menarik, dan menyenangkan.

\section{Daftar Pustaka}

Blachowich, C. \& Peter, F. (1996). Teaching vocabulary in all classroom. Englewood Cliffs: Prentice-Hall, Ltd.

Brown, H. D. 2001. Teaching by principles: An interactive approach to language pedagogy. (2nd ed.) New York: Addison Wesley Longman, Inc.

Burns, A. 1999. Collaborative action research for english language teachers. Cambridge: Cambridge University Press.

Nation, P. 2002. Managing vocabulary learning. Bloomington: Pantagraph. . (Ed.). 1994. New ways in teaching vocabulary. Alexandria: TESOL, Inc.

Nurgiyantoro, B. 2001. Penilaian dalam pengajaran bahasa dan sastra. Yogyakarta: BPFE.

Patrick, J. F. 1996. Helping children learn to read. New York: Random House.

Pearson, P. D. \& Johnson, D. 1984. Semantic feature analysis. Journal of Reading Quest Strategies. http://curry.edschool.virginia.edu/go/readquest/strat/sfa.html

Purwo, B. K. 1997. Pragmatik dan Pengajaran Bahasa. Yogyakarta: Kanisius.

Ramli. 2002. Hubungan penguasaan kosakata dan struktur kalimat dengan pemahaman informasi. Linguistik Indonesia. Tahun 20, Nomor 2, halaman 219.

Roestiyah. 1994. Masalah pengajaran. Jakarta: Rineka Cipta.

Sardiman, A. M. 1994. Interaksi dan motivasi belajar mengajar. Jakarta: Raja Grafindo Persada. 
Syafi'ie, I. 1994. "Metodologi pengajaran bahasa Indonesia." Jurnal Pendidikan Humaniora \& Sains. Th. 1, No. 1, halaman $13-28$.
Tierney, R. J. 1990. Reading strategies and practice: A compedium. Boston: Allyn and Bacon. 